\title{
Iridoids and Sesquiterpenoids with NGF-Potentiating Activity from the Rhizomes and Roots of Valeriana fauriei
}

\author{
Yuanqiang Guo, ${ }^{a}$ Jing Xu,,${ }^{b}$ Yushan $\mathrm{LI},{ }^{b}$ Ryuichi Watanabe, ${ }^{c}$ Yasukatsu Oshima, ${ }^{c}$ \\ Tohru YAMAKUni, ${ }^{a}$ and Yasushi OHIZUMI ${ }^{*, a}$ \\ ${ }^{a}$ Department of Pharmaceutical Molecular Biology, Graduate School of Pharmaceutical Sciences, Tohoku University; \\ Sendai 980-8578, Japan: ${ }^{b}$ Research Department of Natural Medicine, Shenyang Pharmaceutical University; Shenyang \\ 110016, P. R. China: and ${ }^{c}$ Laboratory of Bioorganic Chemistry,, Graduate School of life Sciences, Tohoku University; \\ Sendai 981-8555, Japan. Received July 25, 2005; accepted October 19, 2005
}

\begin{abstract}
A new iridoid glycoside, 10-isovaleryl kanokoside $C$ (1), and a new sesquiterpene (2) together with two known compounds $(3,4)$ were isolated from the rhizomes and roots of Valeriana fauriei. Their structures were elucidated on the basis of spectroscopic analysis. Compounds 2 and 4 showed enhancing activity of nerve growth factor (NGF)-induced neurite outgrowth in PC 12D cells.
\end{abstract}

Key words Valeriana fauriei; iridoid glycoside; sesquiterpenoid; nerve growth factor (NGF)-potentiating activity

Pharmacology on nerve growth factor (NGF) has been subjected to extensive studies, indicating that these substances are theoretically and clinically important in the central nervous system. In the course of our survey on pharmacologically active substances in medicinal plants, much attention has been given to the occurrence of compounds having NGF-potentiating activity, ${ }^{1-3)}$ since these compounds are expected to be potentially useful for the medical treatment of dementia. ${ }^{4)}$ During our search for new types of natural products possessing a NGF-potentiating activity from plants, we investigated the chemical constituents of the crude drug Japanese valerian, 'kisso-kon', from the rhizomes and roots of Valeriana fauriei BRIQUET (Valerianaceae), which mainly contain kessane sesquiterpenoids and iridoid glycosides and have been used for sedative and antispasmodic purposes in the previous literature. ${ }^{5-7)}$ The methanol extract was repeatedly subjected to silica gel column chromatography, followed by reversed-phase HPLC on a ODS column to yield a new iridoid glycoside, 10-isovaleryl kanokoside C (1), a new sesquiterpene (2), one known iridoid $(3)^{8)}$ and one known sesquiterpene (4). ${ }^{7)}$ In this paper, we report the isolation, and structural elucidation of the new compounds and their biological activities as enhancers of NGF action.

Compound 1 was obtained as amorphous colorless solid. The FAB-MS of 1 revealed the $[\mathrm{M}+\mathrm{Na}]^{+}$ion peak at $m / z$

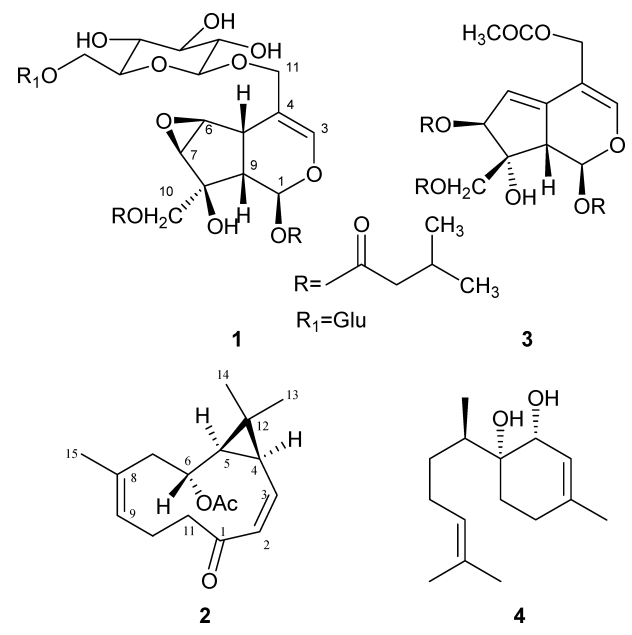

745 in the positive-ion mode, which suggested a molecular formula of $\mathrm{C}_{50} \mathrm{H}_{42} \mathrm{O}_{5}$ for 1 . The ${ }^{1} \mathrm{H}$ - and ${ }^{13} \mathrm{C}-\mathrm{NMR}$ spectra (Table 1) of 1 showed characteristic signals for an iridoid glycoside. ${ }^{6,8-12)}$ In the ${ }^{13} \mathrm{C}$-NMR spectrum, in addition to the signals attributable to two glucose moieties and two isovaleryl moieties $(\delta 174.5,44.0,26.8,22.6,22.7,172.8,44.0$, $26.7,22.6,22.7)$, ten carbon signals $(\delta 35.4,43.9,59.8,60.3$, $69.4,69.5,78.4,90.1,108.8,142.8$ ) were displayed for the iridoid skeleton. Among the signals for the iridoid skeleton, $\delta$ 142.8, 108.8, and 90.1 were typical of C-3, C-4, and C-1, respectively. On the basis of ${ }^{1} \mathrm{H}-{ }^{1} \mathrm{H}$ correlations spectroscopy (COSY), heteronuclear multiple quantum coherence (HMQC), and heteronuclear multiple bond coherence (HMBC) spectral analysis, the ${ }^{13} \mathrm{C}-\mathrm{NMR}$ signals at $\delta 35.4$, $59.8,60.3,78.4,43.9,69.4$ and 69.5 , could be assigned respectively to $\mathrm{C}-5, \mathrm{C}-6, \mathrm{C}-7, \mathrm{C}-8, \mathrm{C}-9, \mathrm{C}-10$ and $\mathrm{C}-11$. The spectroscopic data were almost identical to those published for kanokoside $\mathrm{C}^{9}$ ) except for one additional isovaleryl group appeared in 1. Furthermore, the HMBC correlations between H-10 [4.33, 4.27 (each 1H, d, $J=11.4 \mathrm{~Hz}$ )] and the carbonyl carbon $(\delta 174.5)$ of isovaleryl, $\mathrm{H}-1[\delta 6.53(1 \mathrm{H}, \mathrm{s})]$ and the carbonyl carbon ( $\delta$ 172.8) of isovaleryl, revealed two isovaleryl groups at $\mathrm{C}-10$ and $\mathrm{C}-1$, respectively. The $\mathrm{HMBC}$ correlations of $\mathrm{H}-1^{\prime} / \mathrm{C}-11, \mathrm{H}-1^{\prime \prime} / \mathrm{C}-6^{\prime}$ confirmed the two glucose units at $\mathrm{C}-1$ and $\mathrm{C}-6^{\prime}$, respectively. Based on the HMQC, HMBC, and ${ }^{1} \mathrm{H}-{ }^{1} \mathrm{H}$ COSY spectra of $\mathbf{1}$, the proton and carbon signals were assigned unambiguously.

The nuclear Overhauser and exchange spectroscopy (NOESY) spectrum of 1 revealed nuclear Overhauser effect (NOE) correlations among the protons, leading to the relative stereochemistry determination of compound $\mathbf{1}$. Strong NOE interactions were observed between $\mathrm{H}-10$ and $\mathrm{H}-7, \mathrm{H}-7$ and H-6, H-5 and H-9, and H-1 and H-10. A weak interaction between H-6 and H-10 was also showed. These NOE interactions confirm that $\mathrm{H}-1, \mathrm{H}-6, \mathrm{H}-7$ and $\mathrm{CH}_{2} \mathrm{O}-10$ are on the same face of the molecule and H-5, H-9 are on the other face of the molecule. As most of the naturally occurring iridoid glycosides have been reported to have an $\alpha$ orientation for $\mathrm{H}-1$, in the structure of $1, \mathrm{H}-1, \mathrm{H}-6, \mathrm{H}-7$, and $\mathrm{CH}_{2} \mathrm{O}-10$ have been designated as $\alpha$, and the hydroxyl at C-8, H-9 and H-5 as $\beta$. The coupling constants of the anomeric protons at $\delta 4.42$, and 4.40 (each $1 \mathrm{H}, J=7.8 \mathrm{~Hz}$ ) are consistent with the 
Table 1. NMR Data of Compounds 1 in $\left.\mathrm{CD}_{3} \mathrm{OD}^{a}\right)\left({ }^{1} \mathrm{H}-\mathrm{NMR} 500 \mathrm{MHz}\right.$ ${ }^{13} \mathrm{C}-\mathrm{NMR} 125 \mathrm{MHz}$ )

\begin{tabular}{|c|c|c|}
\hline No. & $\delta_{\mathrm{H}}$ & $\delta_{\mathrm{C}}$ \\
\hline 1 & $6.53(1 \mathrm{H}, \mathrm{s})$ & 90.1 \\
\hline 3 & $6.47(1 \mathrm{H}, \mathrm{d}, J=1.8 \mathrm{~Hz})$ & 142.8 \\
\hline 4 & & 108.8 \\
\hline 5 & $3.13(1 \mathrm{H}, \mathrm{d}, J=7.8 \mathrm{~Hz})$ & 35.4 \\
\hline 6 & $4.11(1 \mathrm{H}, \mathrm{d}, J=2.4 \mathrm{~Hz})$ & 59.8 \\
\hline 7 & $3.37(1 \mathrm{H}, \mathrm{m})$ & 60.3 \\
\hline 8 & & 78.4 \\
\hline 9 & $2.14(1 \mathrm{H}, \mathrm{d}, J=7.8 \mathrm{~Hz})$ & 43.9 \\
\hline \multirow[t]{2}{*}{10} & $4.33(1 \mathrm{H}, \mathrm{d}, J=11.4 \mathrm{~Hz})$ & 69.4 \\
\hline & $4.27(1 \mathrm{H}, \mathrm{d}, J=11.4 \mathrm{~Hz})$ & \\
\hline \multirow[t]{2}{*}{11} & $4.37(1 \mathrm{H}, \mathrm{d}, J=12.0 \mathrm{~Hz})$ & 69.5 \\
\hline & $4.26(1 \mathrm{H}, \mathrm{d}, J=12.0 \mathrm{~Hz})$ & \\
\hline \multicolumn{3}{|l|}{ Sugars } \\
\hline $1^{\prime}$ & $4.42(1 \mathrm{H}, \mathrm{d}, J=7.8 \mathrm{~Hz})$ & 101.9 \\
\hline $2^{\prime}$ & $3.26(1 \mathrm{H}, \mathrm{dd}, J=9.0,7.8 \mathrm{~Hz})$ & 75.0 \\
\hline $3^{\prime}$ & $3.31(1 \mathrm{H}, \mathrm{m})$ & 77.9 \\
\hline $4^{\prime}$ & $3.34(1 \mathrm{H}, \mathrm{m})$ & 71.6 \\
\hline $5^{\prime}$ & $3.50(1 \mathrm{H}, \mathrm{m})$ & 77.0 \\
\hline \multirow[t]{2}{*}{$6^{\prime}$} & $3.81(1 \mathrm{H}, \mathrm{m})$ & 70.0 \\
\hline & $4.19(1 \mathrm{H}, \mathrm{dd}, J=11.4,6.6 \mathrm{~Hz})$ & \\
\hline $1^{\prime \prime}$ & $4.40(1 \mathrm{H}, \mathrm{d}, J=7.8 \mathrm{~Hz})$ & 105.0 \\
\hline $2^{\prime \prime}$ & $3.26(1 \mathrm{H}, \mathrm{dd}, J=9.0,7.8 \mathrm{~Hz})$ & 75.1 \\
\hline $3^{\prime \prime}$ & $3.39(1 \mathrm{H}, \mathrm{m})$ & 78.0 \\
\hline $4^{\prime \prime}$ & $3.37(1 \mathrm{H}, \mathrm{m})$ & 71.7 \\
\hline $5^{\prime \prime}$ & $3.40(1 \mathrm{H}, \mathrm{m})$ & 78.0 \\
\hline \multirow[t]{2}{*}{$6^{\prime \prime}$} & $3.71(1 \mathrm{H}, \mathrm{dd}, J=12.0,5.4 \mathrm{~Hz})$ & 62.7 \\
\hline & $3.90(1 \mathrm{H}, \mathrm{dd}, J=12.0,6.0 \mathrm{~Hz})$ & \\
\hline \multirow[t]{5}{*}{ 1-Isovaleryl } & & 172.8 \\
\hline & $2.21(1 \mathrm{H}, \mathrm{dd}, J=7.2,2.4 \mathrm{~Hz})$ & 44.0 \\
\hline & $2.07(1 \mathrm{H}, \mathrm{m})$ & 26.7 \\
\hline & $0.97(1 \mathrm{H}, \mathrm{d}, J=6.6 \mathrm{~Hz})$ & 22.6 \\
\hline & $0.97(1 \mathrm{H}, \mathrm{d}, J=6.6 \mathrm{~Hz})$ & 22.7 \\
\hline \multirow[t]{5}{*}{ 10-Isovaleryl } & & 174.5 \\
\hline & $2.31(1 \mathrm{H}, \mathrm{d}, J=7.2 \mathrm{~Hz})$ & 44.0 \\
\hline & $2.12(1 \mathrm{H}, \mathrm{m})$ & 26.8 \\
\hline & $0.99(1 \mathrm{H}, \mathrm{d}, J=6.6 \mathrm{~Hz})$ & 22.6 \\
\hline & $0.99(1 \mathrm{H}, \mathrm{d}, J=6.6 \mathrm{~Hz})$ & 22.7 \\
\hline
\end{tabular}

a) All assignments based on the extensive 1D and 2D NMR spectra (HMQC HMBC, DQF-COSY, NOESY)

$\beta$-configuration for both sugar resides. Thus, the compound $\mathbf{1}$ was confirmed as 10-isovaleryloxy kanokoside C.

Compound 2 was isolated as white powder. Its molecular formula was determined to be $\mathrm{C}_{17} \mathrm{H}_{24} \mathrm{O}_{3}$ by high resolution electron impact (HR-EI)-MS $(m / z 276.1715)$. From the molecular formula, the signals in the ${ }^{1} \mathrm{H}$-, and ${ }^{13} \mathrm{C}-\mathrm{NMR}$ data (Table 2) and the correlations in the HMQC spectrum of 2 , it contained 4 quaternary carbons $(\mathrm{C}-1, \mathrm{C}-8, \mathrm{C}-12$, 6-OCOCH 3 ), 6 methines (C-2, C-3, C-4, C-5, C-6, C-9), 3 methylenes (C-7, C-10, C-11), and 4 methyls (C-13, C-14, $\mathrm{C}-15,6-\mathrm{OCOCH}_{3}$ ) composing a bicyclic sesquiterpene. According to the data of ${ }^{1} \mathrm{H},{ }^{13} \mathrm{C}$ and HMQC spectra, the carbon signals at $\delta 194.1,143.7$, and 152.9 were assigned to $\mathrm{C}-1, \mathrm{C}-2, \mathrm{C}-3$ of the $\alpha, \beta$ unsaturated carbonyl moiety in $\mathbf{2}$, respectively. In addition, the one dimensional (1D) and $2 \mathrm{D}$ NMR spectra suggested the existence of cyclopropane moiety $[\mathrm{C}-4(\delta 30.5), \mathrm{C}-5(\delta 39.4), \mathrm{C}-12(\delta 22.3)]$ and another double bond moiety $-\underline{\mathrm{C}}\left(\underline{\mathrm{CH}}_{3}\right)=\underline{\mathrm{CH}}-[\delta 132.7(\mathrm{C}-8), 127.4$ (C-9), 18.0 (C-15)] in 2. The linkage of these moieties was deduced from the HMBC correlations (Fig. 1). In the HMBC spectrum of 2 , the proton signal of $\mathrm{H}-4[\delta 1.70(1 \mathrm{H}, \mathrm{t}$, $J=10.0,9.5 \mathrm{~Hz})]$ showed correlations with the carbon signal
Table 2. NMR Data of Compounds 2 in $\left.\mathrm{CDCl}_{3}{ }^{a}\right)\left({ }^{1} \mathrm{H}-\mathrm{NMR} 500 \mathrm{MHz},{ }^{13} \mathrm{C}\right.$ NMR $125 \mathrm{MHz}$ )

\begin{tabular}{clr}
\hline \hline No. & \multicolumn{1}{c}{$\delta_{\mathrm{H}}$} & $\delta_{\mathrm{C}}$ \\
\hline 1 & & 194.1 \\
2 & $9.29(1 \mathrm{H}, \mathrm{s})$ & 143.7 \\
3 & $6.34(1 \mathrm{H}, \mathrm{d}, J=9.7 \mathrm{~Hz})$ & 152.9 \\
4 & $1.70(1 \mathrm{H}, \mathrm{t}, J=10.0,9.5 \mathrm{~Hz})$ & 30.5 \\
5 & $1.29(1 \mathrm{H}, \mathrm{t}, J=11.0,10.0 \mathrm{~Hz})$ & 39.4 \\
6 & $4.46(1 \mathrm{H}, \mathrm{dd}, J=11.0,4.5 \mathrm{~Hz})$ & 72.0 \\
7 & $\mathrm{H}_{\alpha} 2.26(1 \mathrm{H}, \mathrm{m})$ & 46.3 \\
& $\mathrm{H}_{\beta} 2.23(1 \mathrm{H}, \mathrm{m})$ & \\
8 & & 132.7 \\
9 & $5.23(1 \mathrm{H}, \mathrm{dd}, J=11.0,4.5 \mathrm{~Hz})$ & 127.4 \\
10 & $\mathrm{H}_{\alpha} 2.15(1 \mathrm{H}, \mathrm{m})$ & 27.2 \\
& $\mathrm{H}_{\beta} 2.08(1 \mathrm{H}, \mathrm{m})$ & 23.9 \\
11 & $\mathrm{H}_{\alpha} 1.98(1 \mathrm{H}, \mathrm{m})$ & 22.3 \\
& $\mathrm{H}_{\beta} 2.76(1 \mathrm{H}, \mathrm{m})$ & 28.2 \\
12 & & 15.6 \\
13 & $1.17(3 \mathrm{H}, \mathrm{s})$ & 18.0 \\
14 & $1.17(3 \mathrm{H}, \mathrm{s})$ & 21.3 \\
15 & $1.34(3 \mathrm{H}, \mathrm{s})$ & \\
$6-\mathrm{OAc}$ & & \\
$6-\mathrm{OAc}$ & $2.04(3 \mathrm{H}, \mathrm{s})$ & \\
\hline
\end{tabular}

a) All assignments based on the extensive 1D and 2D NMR spectra (HMQC, HMBC, DQF-COSY, NOESY)

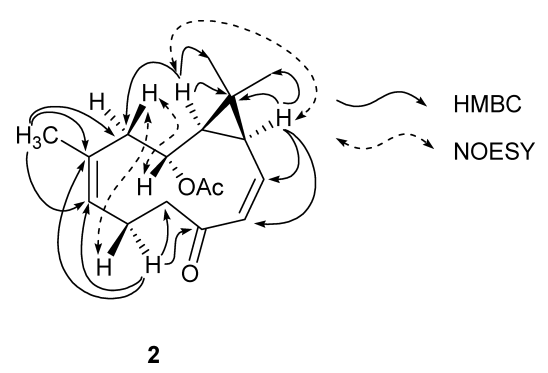

Fig. 1. Selected HMBC and NOESY Correlations of Compound 2

of C-5 ( $\delta$ 39.4), C-6 ( $\delta$ 72.0), C-12 $(\delta 22.3), \mathrm{C}-13(\delta$ 28.2), $\mathrm{C}-14\left(\delta\right.$ 15.6), $s p^{2}$ carbon signals of C-2 $(\delta 143.7)$ and $\mathrm{C}-3$ ( $\delta$ 152.9) of the $\alpha, \beta$ unsaturated keto-carbonyl moiety. The proton signal of $\mathrm{H}-5[\delta 1.29(1 \mathrm{H}, \mathrm{t}, J=11.0,10.0 \mathrm{~Hz})]$ indicated long range correlations with the carbon signals of C-6 $(\delta$ 72.0), C-7 ( $\delta$ 46.3), C-4 ( $\delta$ 30.5), C-12 ( $\delta$ 22.3), C-13 $(\delta$ 28.2), and $\mathrm{C}-14(\delta$ 15.6). The correlations between proton signal of $\mathrm{H}-9[\delta 5.23(1 \mathrm{H}, \mathrm{dd}, J=11.0,4.5 \mathrm{~Hz})]$ and the carbon signals of C-7 $(\delta 46.3), \mathrm{C}-8$ ( $\delta$ 132.7), C-10 ( $\delta$ 27.2), and $\mathrm{C}-11(\delta 23.9), \mathrm{H}-11[\delta 1.98(1 \mathrm{H}, \mathrm{m})]$ and the carbonyl carbon $\mathrm{C}-1$ ( $\delta$ 194.3), and $s p^{2}$ carbon $\mathrm{C}-2(\delta$ 143.7) were also observed in HMBC spectrum. The relative stereochemical structure was revealed by NOESY spectrum. The NOESY correlations of $\mathrm{H}-2 / \mathrm{H}-3$ and the coupling constant $\left(J_{2,3}=0 \mathrm{~Hz}\right)$ showed that $\Delta^{2,3}$ was $Z$ conformation. Another double bond at C-8 and C-9 were determined to be $Z$ conformation by the strong NOESY correlations of $\mathrm{H}_{3}-15 / \mathrm{H}-9$. The NOE correlations of $\mathrm{H}-5 / \mathrm{H}-4$ suggested the same $\alpha$ orientation of H-4 and H-5. The proton signal of H-6 showed NOESY correlations with H-7 $\beta$ which indicated the $\alpha$ confirmation of $6-\mathrm{OCOCH}_{3}$. In addition, we also observed the following correlations of $\mathrm{H}-7 \beta / \mathrm{H}-10 \beta, \mathrm{H}-11 \beta / \mathrm{H}-10 \beta$, $\mathrm{H}-11 \alpha / \mathrm{H}-10 \alpha$ in the NOESY spectrum of 2 . Based on the above spectral analysis, this compound was identified to be 2 . Full assignments of ${ }^{1} \mathrm{H}$ - and ${ }^{13} \mathrm{C}-\mathrm{NMR}$ signals were estab- 


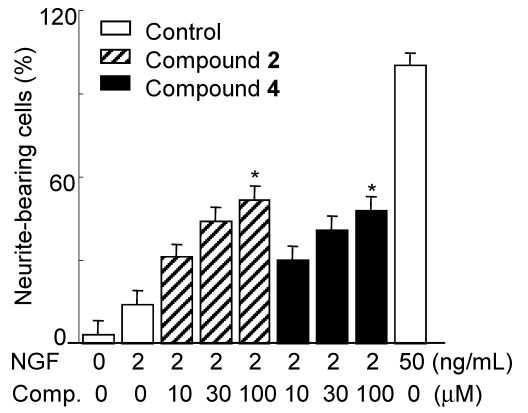

Fig. 2. Effects of Compounds $\mathbf{2}$ and $\mathbf{4}$ on the Proportion of Neurite-Bearing PC12D Cells in the Presence or Absence of NGF

The proportion of neurite-bearing cells is expressed as a percentage against the maximum response to NGF $(50 \mathrm{ng} / \mathrm{ml}, 100 \%)$ in the absence of compounds. Values are mean \pm S.E. from four experiments. A statistically significant difference $(* p<0.01)$ from the control ( $2 \mathrm{ng} / \mathrm{ml} \mathrm{NGF)}$ in the absence of compounds was apparent.

lished by the detailed analysis of ${ }^{1} \mathrm{H}-{ }^{1} \mathrm{H}$ COSY, HMQC, HMBC, and NOESY spectra.

From the $\mathrm{MeOH}$ extract of the rhizomes and roots of $V$. fauriei, one known iridoid (3) and one known sesquiterpene (4) were also isolated and identified by comparison of their spectroscopic data with those in the literature. ${ }^{7,8)}$ The propensity of $\mathbf{1}-\mathbf{4}$ to enhance the effects on the NGF to stimulate neurite outgrowth from PC12D cells was assessed as previously reported. ${ }^{13)}$ In control experiments, the percentages of neurite-bearing cells were $14 \%$ and $100 \%$ following incubation with 2 and $50 \mathrm{ng} / \mathrm{ml} \mathrm{NGF}$ after $48 \mathrm{~h}$, respectively. Compounds 2 and $\mathbf{4}(10,30,100 \mu \mathrm{mol})$ had no effect on neurite outgrowth from PC12D cells in the absence of NGF, but markedly at $100 \mu \mathrm{mol}$ increased the NGF ( $2 \mathrm{ng} / \mathrm{ml})$-induced proportion of neurite-bearing cells by $52 \%$ and $48 \%$, respectively. However, compounds $\mathbf{1}$ and $\mathbf{3}$ showed no activity on proportion of neurite-bearing cells in the absence or presence of NGF $(2 \mathrm{ng} / \mathrm{ml})$. The comparison of the activities with that of nardosinone, a enhancer of NGF action, $\left.{ }^{13}\right)$ suggested the moderate NGF-potentiating activities of $\mathbf{2}$ and $\mathbf{4}$, which may be potentially useful for the medical treatment of dementia.

\section{Experimental}

General Experimental Procedures Melting points were measured on a Yanaco micro-melting point apparatus without correction. Optical rotations were measured with a JASCO DIP-370 polarimeter. The ultraviolet spectra were recorded on a Shimadzu UV-260 spectrophotometer, and the infrared spectra were obtained on a Shimadzu IR-408 spectrometer. 1D and 2D NMR spectra were recorded in $\mathrm{CD}_{3} \mathrm{Cl}_{3}$ or $\mathrm{CD}_{3} \mathrm{OD}$ on a JEOL ECP-500 and ECP600 instruments. Preparative HPLC separations were performed on a Shimadzu LC-6A, equipped with UV-7000 detector at $205 \mathrm{~nm}$, and a J'Sphere ODS-M80 $(250 \times 20 \mathrm{~mm})$ column. EI-MS and HR-EI-MS were recorded on JMS DX-303 and JMS AX-700, respectively. FAB-MS and HR-FAB-MS were recorded on JMS-700 spectrometer. Chemicals for the biological studies were purchased from Wako Pure Chemical (Tokyo, Japan).

Plant Material The rhizomes and roots of $V$. fauriei were bought from Japanese drugstore, in Aug. 2004. The botanical identification was made and a voucher specimen (No. 68535) was deposited in the Graduate School of Pharmaceutical Sciences, Tohoku University (Sendai, Japan).
Extraction and Isolation The rhizomes and roots of $V$. fauriei $(3 \mathrm{~kg})$ were extracted with $\mathrm{MeOH}$ (9l) three times, and the $\mathrm{MeOH}$ extract (590 g) was partitioned by EtOAc, $n$ - $\mathrm{BuOH}$, and $\mathrm{H}_{2} \mathrm{O}$. The EtOAc-soluble fraction $(211 \mathrm{~g})$ was subjected to silica gel $(500 \mathrm{~g} ; 70-230 \mathrm{mesh})$ column chromatography, using gradient of EtOAc in $n$-Hexane to give 10 fractions (110). Then fraction 6 was chromatographed by HPLC (YMC-Pack J'Sphere ODS-M $80,250 \times 20 \mathrm{~mm}, 77 \% \mathrm{MeOH}$ in $\mathrm{H}_{2} \mathrm{O}$, UV detector, $205 \mathrm{~nm}$ ) to afford compounds $2(6.2 \mathrm{mg})$ and $4(5.7 \mathrm{mg})$. Compound $3(5.3 \mathrm{mg})$ was isolated from fraction 7 by HPLC (YMC-Pack J'Sphere ODS-M80, $250 \times 20 \mathrm{~mm}, 68 \% \mathrm{MeOH}$ in $\mathrm{H}_{2} \mathrm{O}$, UV detector, $205 \mathrm{~nm}$ ). The Silica gel column chromatography of $n$-BuOH part and further purification by preparative HPLC (YMC-Pack J'Sphere ODS-M80, $250 \times 20 \mathrm{~mm}, 34 \% \mathrm{MeOH}$ in $\mathrm{H}_{2} \mathrm{O}$, UV detector, $205 \mathrm{~nm}$ ) resulted in the isolation of an iridoid glycoside 1 (7.0 mg).

Compound 1: Amorphous; $[\alpha]_{\mathrm{D}}^{26}-68.5^{\circ}(c=0.5, \mathrm{MeOH})$. UV $\lambda_{\max }$ (MeOH) nm: 208.0; IR $v_{\max }$ (film) $\mathrm{cm}^{-1}: 3421,2959,1738,1675,1635$, 1372. ${ }^{1} \mathrm{H}$ - and ${ }^{13} \mathrm{C}-\mathrm{NMR}$ see Table 1 . Positive-ion FAB-MS $745[\mathrm{M}+\mathrm{Na}]^{+}$, Positive-ion HR-FAB-MS 745.2903 (Calcd for $\mathrm{C}_{50} \mathrm{H}_{42} \mathrm{O}_{5} \mathrm{Na}$, 745.2895).

Compound 2: White powder $(\mathrm{MeOH}), \mathrm{mp} 94-96^{\circ} \mathrm{C}$; UV $\lambda_{\max }(\mathrm{MeOH})$ nm: 254.0; $[\alpha]_{\mathrm{D}}^{26}+349.4^{\circ}(c=0.5, \mathrm{MeOH}) ; \mathrm{IR} v_{\max }($ film $) \mathrm{cm}^{-1}: 1779,1718$; ${ }^{1} \mathrm{H}-$ and ${ }^{13} \mathrm{C}-\mathrm{NMR}$ see: Table 2. EI-MS $\mathrm{m} / \mathrm{z}: 276[\mathrm{M}]^{+}$; HR-EI-MS $\mathrm{m} / \mathrm{z}$ : 276.1715 (Calcd for $\mathrm{C}_{17} \mathrm{H}_{24} \mathrm{O}_{3}, 276.1725$ ).

Bioassay Procedure PC12D cells were dissociated by incubation with $1 \mathrm{mmol}$ of ethylene glycol-bis(2-aminoethyl ether)- $N, N, N^{\prime}, N^{\prime}$-tetraacetic acid (EGTA) in phosphate-buffered saline (PBS) for $30 \mathrm{~min}$ and then were seeded in 24 -well culture plates $\left(2 \times 10^{4}\right.$ cells/well) coated with poly-L-lysine. After $24 \mathrm{~h}$, the medium was changed to test medium containing various concentrations of NGF $(50 \mathrm{ng} / \mathrm{ml}$ for positive control, $2 \mathrm{ng} / \mathrm{ml}$ for test samples and significant difference control), $1 \%$ fetal calf serum, $2 \%$ horse serum, and various concentrations of test compounds $(10,30,100 \mu \mathrm{mol})$. After $48 \mathrm{~h}$, the cells were fixed with $1 \%$ glutaraldehyde at $37^{\circ} \mathrm{C}$. The neurite outgrowth was assessed under a phase-contrast microscope. Neurite processes with a length equal to or greater than the diameter of the neuron cell body were scored as a neurite-bearing cell. The ratio of the neurite-bearing cells to total cells (with at least 100 cells examined/viewing area; 3 viewing areas/well; 6 wells/sample) was determined and expressed as a percentage. Statistical comparisons were made using Student $t$-test.

Acknowledgments This research was supported in part by a Grant-inAid for Scientific Research from the Ministry of Education, Culture, Sports, Science and Technology of Japan.

\section{References}

1) Li P., Matsunaga K., Ohizumi Y., Biol. Pharm. Bull., 23, 890-892 (2000).

2) Li Y., Ohizumi Y., Yakugaku Zasshi, 124, 417-424 (2004).

3) Li Y., Ohizumi Y., Pharmacometrics, 66, 133-139 (2004).

4) Brinton R., Yamazaki R., Pharm. Res., 15, 386-388 (1998).

5) Oshima Y., Matsuoka S., Ohizumi Y., Chem. Pharm. Bull., 43, 169170 (1995).

6) Koichi N., Takefumi K., Koichi T., Hideji I., Phytochemistry, 31, 3511-3514 (1992).

7) Koichi N., Takefumi K., Koichi T., Hideji I., Phytochemistry, 36, $1547-1548$ (1994).

8) Tang Y. P., Liu X., Yu B., J. Nat. Prod., 65, 1949-1952 (2004).

9) Kuruuzum-uz A., Guvenalp Z., Demirezer L., O., Bergere I., Stroch K., Zeeck A., Phytochemistry, 61, 937-941 (2002).

10) Rimpler H., Planta Med., 33, 313-317 (1978).

11) Byrne L. T., Sasse J. M., Skelton B. M., Suksamrarn A., White A. H., Aust. J. Chem., 40, 785-794 (1987).

12) Boros C. A., Stermitz F. R., J. Nat. Prod., 54, 1173-1246 (1991).

13) Li P., Matsunaga K., Yamamoto K., Yoshikawa R., Kawashima K., Ohizumi Y., Neuroscience Lett., 273, 53-56 (1999). 